\title{
QUALITY EVALUATION OF BUTTER SOLD IN ALEXANDRLA MARKETS
}

\author{
Sawsan. M. L. El-Sheshnagui., Nablla, F. El-Sayed \& Wafaa, M. Elssa \\ Animal Health Research Institute. Alexadra \\ Department of Food Hyglene Researchs
}

\begin{abstract}
A total of 60 butter samples $(20$ of each of imported cow butter, locally produced cow butter and locally produced buffalo butter) were collected aseptically from different Alexandria markets. The samples were subjected to microblological and chemical examination to evaluate its sanitary condition on the basis of Egyptian organization for Standardization and Quality Control, 2005 specifications. The results of the current study revealed that 20\%, 40\% and 55\% of the examined imported butter. locally produced cow butter and locally produced buffalo butter samples exceeded the maximum

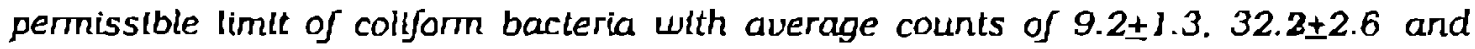
$38 \pm 5.8 \mathrm{MPN} / \mathrm{g}$ respectlvely. However, $35 \%, 55 \%$ and $75 \%$ of such samples were over the permissible limit of total yeast and mold count with average counts of $3.4 \times 10 \pm$ $1.5 \times 10,5.8 \times 10^{2} \pm 1.6 \times 10^{2}$ and $5.2 \times 10^{3} \pm 2.3 \times 10^{2} \mathrm{c}$. .u/g. Lipolytic and psychrotrophtc bacterla were tsolated from all of the examined samples with counts exceeding the allowable limit. $19.1 \times 10 \pm .1 .1 \times 10,4.1 \times 10^{3} \pm 2.6 \times 10$ and $5.9 \times 10^{2} \pm 6.1 \times 10 \mathrm{c}$. $. \mathrm{u} / \mathrm{g}$ for lip. olytic and $3.5 \times 10^{2} \pm 1.3 \times 10^{2}, 6.5 \times 102 \pm 2.9 \times 10^{2}$ and $5.5 \times 10^{3} \pm 8.2 \times 10$ c.f.u/g for psychrotrophic bacterial.Salmonella could not be detected but Shigella was isolated from one sample only representing $5 \%$ of locally produced cow butter samples. Staphylococcus aureus was detected in 4046.55\% and 60\% while Listeria species in the order of 25\%, $15 \%$ and $10 \%$ of imported butter, locally produced cow butter and locally produced buffalo butter samples respectively. The chemical examination showed that $10 \%, 50 \%$ and 100\% of such samples respectwely were above the allowable limit for moisture content. Sodium chloride content was above the permissble limit in $25 \%$ of locally produced cow butter and $35 \%$ of locally produced buffalo butter.
\end{abstract}

\section{INTRODUCTION}

Butter is esscntially the fat of milk. It is a water-in-oll emulsion. Commcrcial butter is composed of $80 \%-82 \%$ milk fat. $16 \%-17 \%$ water and $1 \%-2 \%$ milk solid-not-fat isometimes referred to as curd). It may contain salt, addcd directly to the butter In concenura- tions of 1\%-2\%. Unsalted butter is often referred to as "sweet butter". This should not be confused with "sweet cream" butter, whlch may or may not be salted. Reduced-fat or "light" butter usually contalns about $40 \%$ milk fat. Butter also contain proteln, ealclum and phosphorous and rat-soluble vitamins 
Collform baetena in a sample of butter probably would Indicate gross contamination in most instances, but thcre are circumstances when considerable number of these organisms may occur evcri In salced butter.

Psychotrophic bacterla are those able to grow at $70 \mathrm{C}$ or less regardless of their optimal growth temperature. Psychotrophic bacteria that are commonly isolated from dalry products belong to a vartety of genera, but In general, these bacteria are non-pathogenlc. Some pathogenic bacterla are psychotrophlc $(\mathrm{eg}$. Listerla monocytogenes (Frank et al., 1992). if butter has been eontaminated in the manufacturing process and if conditions such as poor water dispersion and high temperature favor microblal growth. spollage may occur. Psychrotrophic bactena are predominant in this type of detenoration and when present in butter. they can cause a varlety of butter derects. (Cousin, 1982).

Sabreen (1996) recorded a mean count of $26 \times 10 / g$ and $19 \times 10 / g$ for Psychotrophic bacterla In imported and local butter respectively.

An Increasing problem is lipolysis in butterfal after manufacturing, which is caused by themoresistant lipase enzymes that are created in the milk or cream by psychotrophic bactena or by residual natlve lipases that survive pasteurization (Sabreen, 1996). Lipolytic and proteolytic bacteria produce enzymes during their growth in milk from which cream used for butter making. These enzymes remaln aclive after heat treatment and can damage the qualtity of butter (lawrence, 1967). Most of psychrotrophic and thermodurlc bacteria. yeasts and molds have the ablitry of proteolyses and lipolysis (APHA. 1985). The enumeration of llpolytic bacteria in butter may be helpful in drawing attention to unsatisfactory manufacturing and handling procedurcs. Average count of $7.5 \times 10^{5} \mathrm{c.f.u} / \mathrm{g}$ of butter for lipolytic bacterta was recorded by Patir, et al., 1905. While in Egypt ElDemerdash, (1980) reported eounts of $16.7 \times 10^{3}$ vs and $19.3 \times 10^{3}$ for lipolytic bactena in imported and local butter samples respectively.

High mold and yeast count may be attributed to the faulty methods in proeessing specially in connection with inadequate sanitation of the churn. Inefnclent pasteurization. low sait content. improper conditions of storage or a comblnation of any of these may be responsibie for high counts. The evidence avallable Indicates that there is a tendency for butter with low moid and yeast counts to possess better keeplng quallty than butter with high counts. Yeasts and molds do not survive pasteurization. When present in butter, they Indicate faulty sanitation and alr contamnation (Murphy, 1990). Aman, (1986) recorded an average yeast and mold count of $99 \times 10 / \mathrm{g}$ of cooklng butter whlle a mean count of $2.5 \times 10 / g$ of cooklng butter was reported by Ahmed et al., (1987). Mohmad et al., (1983) detected a mean yeast count of $41.87 \times 10 / \mathrm{g}$ and a mean mould count of $55.2 \times 10 / \mathrm{g}$ of cooking butter respectively. While Tasnlm et al., (1993), Rajaraman et al. (1994) and Pather et al., (1985) recorded mean counts of $3.84 \times 10 / g$ and $8.3 \times 10 / g$ and $9 \times 10 / g$ of table butter for yeast and mould respectively.

Durng the current study. Salmonella specles could not be detected while Shigella spe- 
cles was isolated from one sample only represenung $5 \%$ of locally produced cow butter samples. Staphylococcus aureus was detected In 40\%. 55\% and 60\% while Listerla specles In the order of $25 \%, 15 \%$ and $10 \%$ of imported butter. locally produced cow butter and to cally produced buffalo butter samples respectively (table 2).

El-Gazzar Marth, (1995) found that butter readily supported growth of salmonellae at mom temperature. and nelther freezing nor refrigeration for brlef penods eliminated salmonellae from butter. However, Bantos et al., (1995) and Tasnim et al., (1099) falled to detect Salmonella in butter. whlle Staphylococcus aureus (Bantos et al., 1995 and Na2em. 1991). Llisterla Innocua. (Mas8a et al. 1990) were dctected.

In the current study. rcsults of the ehemilcal examination showed that 10\%, 50\% and $100 \%$ of imported cow butter. locally produced cow butter and locally produced buffalo butter samples respectlvely were above the allowable $1 \mathrm{~m}$ it for molsture eontent. Sodium chloride content was above the permissible linit in $25 \%$ of locally produced cow butter and $35 \%$ of locally produced buffalo butter. The sodlum Chloride $\%$ of the examined butter samples was presented In Table (3). Lower results of a range of $0.9 \%$ to 1.05 to and a mean to of $0.46 \pm 0.04$ to were obtained by Alad (2002) and 5aleh (1995), while higher salt \% was recorded by Nazem (1991). The $\mathrm{pH}$ values of the examined butter samples were recorded in table (3) reflecting the acidic nature of all of the samples. Nearly simllar results were reeorded by Alad (2002) and lower values by Nawar (2001).
Rancidity can be detected by measuring the acld degree value which determines the presence of free fatty acids. Several studies indicated that a high content of unsaturated fatty aclds In milkfat Increases the rsk of oxidation and production of off-flavors (Im \& Marshall, 1998).

Lewls et al., (2006) stated that three percent salt results in $15.8 \%$ water phase salt butter that is inhlbitory to all food-borne pathogens except Staphylococeus aureus. On the other hand, $1 \%$ salt drops the level in the water phase to $5.9 \%$, which would permit the growth of most food-borne pathogens. The need for ume/temperature control depends on the $\mathrm{pH}$ and of the product, and on whether other preservattves have been added to the formulation.

\section{CONCLUSION}

The safety of butter has been the concern of the modern dally industry as it regards food safety as a critical feature of its produet. Therefore, careful control of proeessing and storage conditions should be applled to ensure the safety of the product for human eonsumption. Due to efflelent hyglenic and modern technology, pathogens are rarely found in heat treated butter. The pathogenic bacterla can contaminate butter If made from contamlnated cream. Moreover, the chanee of postpasteurzation eontamination may exist. Unfortunately. growth of pathogens in butter is not a determinant of shelf-life. That role is played by spollage bacteria.

Careful attention is pald to temperature control in raw-milk-handling systems and. naturally, to the cleaning of all equipment. 
Unfortunately, some of the lipolytic and proteolytic enzymes produced by psychrotrophs are heat stable, even surtulng ultrahigh temperature (UHT) treatment. Today, a shelf life of many months is expected of a number of UHT-treated producls, thus the presence of lipolytic and proteolytic enzymes can be disastrous. The only way to avold this problem is to ensure that the numbers of organlsms are kept to an absolute minimium durng all stages of the collection and manufaeturing process.

\section{Recommendations :}

Monitoring of the sanltary condition of butter and other dairy products during production and handling is an Important task. Quality control and striet hygienic measures should be imposed to improve butter quality espectally in the farm and on the small scale production.

Storing butter properly lengthens the shelf Iffe so It ean be used over a longer period of time. To prevent a type of spotlage called rancidity, protect butter from heat, light and alr by storing it covered in the refrigerator. Rancid butter has an unpleasant taste and smell.

Butter absorbs odors from other foods rapidly. To prevent havor changes, keep buller wrapped in molsture- and vapor-proor mater!al or in ughtly covered contalners. For refrigerator storage, leave butler in lts orighal wrapper. Opened portions of butter should be relrigerated In a coverced dish.

Butter can be storcd for up to two weeks at rerrigerator teinperatures. Higher temperatures causc off-flavors and unpleasant odors to develop. Butter should not be stored in the butter keeper (set at warmer temperatures) on the refrigerator door longer than two days. For ease in spreading. remove butter from the refrigerator 10 to 15 minutes belore using It.

For holding longer than two weeks, butter should be frozen. To store butter in the freezer, wrap It in molsture- and vapor-proof freezer packagling material to keep the butter from absorbing odors from other loods and to prevent freezer bum. 
Sawsan, M. L. El-Sheshnagui; et al...

Table (1): Bacterlal counts of the examined hutter samples from Alexandrla markets.

\begin{tabular}{|c|c|c|c|c|c|c|c|c|c|}
\hline \multirow[t]{2}{*}{ Bacteria } & \multicolumn{3}{|c|}{$\begin{array}{l}\text { Imported } \\
\text { cort } \\
\text { butter }\end{array}$} & \multicolumn{3}{|c|}{$\begin{array}{c}\text { Locally produced } \\
\text { cowt } \\
\text { Butter }\end{array}$} & \multicolumn{3}{|c|}{$\begin{array}{c}\text { Locally produced } \\
\text { buftalo } \\
\text { butter }\end{array}$} \\
\hline & Min & $\max$ & $\begin{array}{c}\text { mean } \\
\pm S E\end{array}$ & $m / n$ & Max & $\begin{array}{l}\text { mean } \\
\pm S E\end{array}$ & mln & $\max$ & $\begin{array}{l}\text { megn } \\
\pm S E\end{array}$ \\
\hline $\begin{array}{l}\text { Coliforms } \\
\text { (MPN/gm) }\end{array}$ & $<$ & 15 & $\begin{array}{l}9.2 \\
\pm \\
1.3\end{array}$ & 15 & 64 & $\begin{array}{c}32.2 \\
\pm \\
2.6\end{array}$ & 7.4 & 160 & $\begin{array}{c}38 \\
\pm \\
5.8\end{array}$ \\
\hline $\begin{array}{c}\text { Yeasl and } \\
\text { mold } \\
\text { (CFU/gm) }\end{array}$ & $1.8 \times 10$ & 8.6210 & $\begin{array}{c}4.3 \times 10 \\
\pm \\
1.5 \times 10\end{array}$ & $\begin{array}{c}1.7 \times 1 \\
0\end{array}$ & $\begin{array}{c}2.9 \times 10 \\
,\end{array}$ & $\begin{array}{c}5.8 \times 10^{2} \\
\pm \\
1.6180^{2}\end{array}$ & $4.2 \times 10$ & $\begin{array}{c}9.6 \times 10 \\
4\end{array}$ & $\begin{array}{c}5.2 \times 10^{\top} \\
\pm \\
1.3 \times 10^{3}\end{array}$ \\
\hline $\begin{array}{l}\text { Ljpolytlc } \\
\text { bacterla } \\
\text { (CFU/gm) }\end{array}$ & $6.3 \times 10$ & $\begin{array}{c}8.2 \times 10 \\
1\end{array}$ & $\begin{array}{c}9.1 \times 10 \\
\pm \\
1.1 \times 10\end{array}$ & $\begin{array}{c}9.2 \times 1 \\
0^{2}\end{array}$ & $\begin{array}{c}5.3 \times 10 \\
3\end{array}$ & $\begin{array}{c}4.1 \times 10^{3} \\
\pm \\
6.2 \times 10\end{array}$ & $\begin{array}{c}7.5 \times 10 \\
2\end{array}$ & $\begin{array}{c}2.3 \times 10 \\
,\end{array}$ & $\begin{array}{c}5.9 \times 10^{1} \\
\pm \\
6.1 \times 10\end{array}$ \\
\hline $\begin{array}{l}\text { Psychotrop } \\
\text { hic bacteria } \\
\text { (CFU/gm) }\end{array}$ & $1.5 \times 10^{2}$ & $\begin{array}{c}8.2 \times 10 \\
1\end{array}$ & $\begin{array}{c}3.5 \times 10^{2} \\
\pm \\
1.3 \times 10^{2}\end{array}$ & $\begin{array}{c}2.3 \times 1 \\
0\end{array}$ & $\begin{array}{c}9.5 \times 10 \\
1\end{array}$ & $\begin{array}{c}6.3 \times 10^{2} \\
\pm \\
2.9 \times 10^{2}\end{array}$ & $\begin{array}{c}4.3 \times 10 \\
3\end{array}$ & $\begin{array}{c}7.6 \times 10 \\
1\end{array}$ & $\begin{array}{c}5.5 \times 10^{3} \\
+ \\
0.2 \times 10\end{array}$ \\
\hline
\end{tabular}

Table (2): bacterlal pathogens tsolated from the examined butter samples from Alexandria markets.

\begin{tabular}{|c|c|c|c|c|c|c|}
\hline \multirow[t]{2}{*}{ Bacteria } & \multicolumn{2}{|c|}{$\begin{array}{c}\text { Imported } \\
\text { cow } \\
\text { butter }\end{array}$} & \multicolumn{2}{|c|}{$\begin{array}{c}\text { Locally produced } \\
\text { cory } \\
\text { Butter }\end{array}$} & \multicolumn{2}{|c|}{$\begin{array}{c}\text { Locally produced } \\
\text { burTalo } \\
\text { hutter }\end{array}$} \\
\hline & $\begin{array}{c}\text { tre } \\
\text { samples }\end{array}$ & $\%$ & $\begin{array}{c}\text { tre } \\
\text { samples }\end{array}$ & $\%$ & $\begin{array}{c}\text { tve } \\
\text { samples }\end{array}$ & $\%$ \\
\hline Eschericia coli & 1 & 5 & 4 & 20 & 3 & 15 \\
\hline Salmonella spp. & - & - & - & - & - & - \\
\hline Shlgella spp. & - & - & 1 & $\mathbf{s}$ & - & - \\
\hline Slaph. aureus & 12 & 60 & 9 & 45 & 6 & 30 \\
\hline Listeria spp. & 5 & 25 & 3 & 15 & 2 & 10 \\
\hline
\end{tabular}


Sawsan, M. L. El-Sheshnagui; et al...

Table (3): Reoultw of chemical eramination of butter anmples from Alerandrle markets

\begin{tabular}{|c|c|c|c|c|c|c|c|c|c|}
\hline \multirow{2}{*}{$\begin{array}{l}\text { Chemical } \\
\text { eramination }\end{array}$} & \multicolumn{3}{|c|}{$\begin{array}{l}\text { Imported } \\
\text { cow } \\
\text { butter }\end{array}$} & \multicolumn{3}{|c|}{$\begin{array}{l}\text { Locally produced } \\
\text { cow } \\
\text { Butter }\end{array}$} & \multicolumn{3}{|c|}{$\begin{array}{l}\text { Locally produced } \\
\text { huftalo } \\
\text { butter }\end{array}$} \\
\hline & miln & $\max$ & $\begin{array}{c}\text { mean } \\
\pm S E\end{array}$ & MID & $\max$ & $\begin{array}{l}\text { megn } \\
\pm S E\end{array}$ & min & $\max$ & $\begin{array}{l}\text { mean } \\
\pm 5 E\end{array}$ \\
\hline$p^{H}$ & 4.5 & 5.8 & $5.2 \pm 0.03$ & 4.99 & 5.99 & $5.4 \pm 0.2$ & 5.3 & 6.1 & $5.5 \pm 0.4$ \\
\hline Acld value & 1.3 & 1.8 & $1.6 \pm 0.09$ & 1.9 & 2.2 & $2.1 \pm 0.06$ & 2.0 & 2.5 & $2.3 \pm 0.1$ \\
\hline Moisture \% & 16.3 & 22.0 & $20 \pm 1.70$ & 25 & 29 & $27 \pm 13$ & 19 & 23 & $21 \pm 0.7$ \\
\hline $\begin{array}{c}\text { Sodlum } \\
\text { chloride \% }\end{array}$ & 0.09 & 1.8 & $1.3 \pm 0.10$ & 1.1 & 2.3 & $1.8 \pm 0.3$ & 1.7 & 3.1 & $2.9 \pm 0.3$ \\
\hline
\end{tabular}

Table (4): Sanitary condition of bulter eamples in compartson with the Egyptian Standard Speciflcatlons (2005)

\begin{tabular}{|c|c|c|c|c|c|c|c|}
\hline \multirow[b]{2}{*}{$\begin{array}{l}\text { Sanitary } \\
\text { parameter }\end{array}$} & \multirow{2}{*}{$\begin{array}{c}\text { Egyptian } \\
\text { Standard } \\
\text { Specifleations } \\
\text { (2005) }\end{array}$} & \multicolumn{2}{|c|}{$\begin{array}{c}\text { Imported } \\
\text { cow } \\
\text { butter }(n-20)\end{array}$} & \multicolumn{2}{|c|}{$\begin{array}{l}\text { Locally produced } \\
\text { cow } \\
\text { Butter }(n-20)\end{array}$} & \multicolumn{2}{|c|}{$\begin{array}{c}\text { Loeally produced } \\
\text { bumulo } \\
\text { Butter }(n-20)\end{array}$} \\
\hline & & 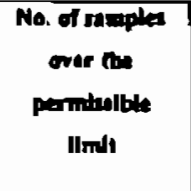 & $x$ & $\begin{array}{c}\text { No. of anmples } \\
\text { over lhe } \\
\text { permisalble } \\
\text { llm/t }\end{array}$ & $x$ & $\begin{array}{l}\text { No. of eamples } \\
\text { Fithin the } \\
\text { perondulble } \\
\text { llmle }\end{array}$ & $x$ \\
\hline Collforms & $<10 / g$ & 4 & 20 & $\overline{8}$ & 40 & 11 & 55 \\
\hline Yeast and mold & 20 & 7 & $\overline{35}$ & 11 & $\overline{35}$ & $\overline{15}$ & 75 \\
\hline Lipolytic bacterla & 0 & 20 & 100 & 20 & 100 & 20 & 100 \\
\hline Paychatrophics & 0 & 20 & 100 & 20 & 100 & 20 & 100 \\
\hline Eschericlo coli & 0 & 1 & $\overline{5}$ & 1 & 5 & 3 & 15 \\
\hline Salmonella spp. & 0 & 0 & 0 & 0 & $\overline{0}$ & 8 & $\overline{0}$ \\
\hline Shlgella spp. & 0 & 0 & 0 & 1 & 5 & 0 & 0 \\
\hline Staph. aureus & $\mathbf{0}$ & $\overline{8}$ & 40 & 11 & 55 & 14 & 60 \\
\hline Listerta spp. & 0 & 5 & 25 & 3 & 15 & 2 & 10 \\
\hline Moisture \% & $48 \%$ & 2 & 10 & 10 & 50 & 20 & 100 \\
\hline Sodlum chlorlde \% & $\leq \%$ & $\overline{0}$ & 8 & 5 & 25 & 7 & 35 \\
\hline
\end{tabular}




\section{REFERENCES}

Ahmed, A. A. Moustafa, M. K. \& Abdel. Haktem, E. H. (1987) : Sanitary condition of cooking butter manifactured In Asslut City. Asslut Med. V(t. J. 19 (37): 82-86.

Alad, A. S. (2002) : Criterla for evaluation of locally manufactured dalry products. A Thesis for PH. D mllk hyglenc. Fac. Vct. Mcd. Alexandria Univ.

Aman, I. M. (1085) : Incidence and signincance of fungl in some dalry products. $M$. V. Scl Thesis, Fac. Vet. Med. Calro Univ.

Andrews, W. H. \& Hammack, T. S. (2001) : Food sampling and preparation of sample homogenate. US FDA/ CFSAN. Bacterlological Analytical Manual, 8th Edition.

Andrews, W. H. \& Hammack, T. 8. (2001): Salmonella. US FDA/ CFSAN. Bacterlological Snalytical Manual. Bth Edition

Andrews, W. H. \& Jacobson, A. (2001): Shigella. US FDA/ CFSAN BAM.

AOAC (1990) : Officlal Methods of Analysls. 15th Ed. VOl. 2 Food Composition. Add1tives, Contaminants. Publ. AOAC Inc. Sulte 40-2200 Wilson Boulevand. Arilngtm, Virginla / USA.

APFA, (1986) : Standard Methods for the Examination of Dalry Products. 15th Ed., American Public Health Assoclation. New York.

Avramis, C. A. Wang, H.: MeBride, B. W.: Wrigh, T. C. Hul, A. R. (2003) : Phys1- cal and processing propertles of mllk. butter. and cheddar cheese from cows led supplemental insh incal. J Dairy Scl. 8G(8): 25682576.

Bennet, R. W. \& Lancette, G. A. (2001) : Staphylococcus aurcus. US FDA/ CFSAN BAM.

Code of Federal Regulations (CFR), (1991) : US Standards for grades of Butter US Government Printing Omce. Washington. DC.

Code of Federal Regulations (CFR), (2006) : Grading and Inspection, General Specifications for Approved Plants and Standards for Grades of Dairy Products 1. PART 58 No. 345 (7CFR 58.345).

CODEX STAN A-1-1971, Rev.1 (1989) : amended in (2006): CODEX standard for butter

Cousln, M. A. (1882) : Presence and actuvlty of Psychrotrophic microorganisms in milk and dalry products. A revlew. J. Food Prot.. 45: 172-207.

El-Demerdash, M. S. (1900) : Chemtcal and bacterlological studies on some local and imported dalry products. M.V.Sc. Thesis, Fac. Agric. Zagazig Univ.

El-Gazzar, F. E. \& Marth, E. H. \{1882\}: Salmonellae. Salmonellosls and dalry foods. A revlew. J. Dalry Scl., 75 (9): 2327-2343.

EOSgC (2003) : Egyptian Organization for Standardization and Quality control. 
ESS154-1/2005.Milk \& Dalry products: natural cow butter.

FDA, (1992) : Evaluation and Definition of Potentlally Hazardous Foods.

Analysis of Microblal Hazards Related to Time/Temperature Control of Foods for Safet $y$, butter and marganne Chapter 4 .

Feng, P., Wegent, 5.D. Grant M.A. (2001): Enumeration of $E$. coll and the collform baetena. US FDA/ CFSAN BAM.

Frank, J. F.; Chribten, G. L. \& Bullerman, L. B. (1992) : Tests for groups of microorganisms. In Slandard Methods for the Examination of Dalry Products. 16th ed. APHA. P. 271,

Genevieve, L. C. (1993) : Analysis. In Dalry Sclence and Technology Handbook. Princlples and Propertles. (Y.H Hul ed.) VCH Publichers lnc. Ncw York. USA.

Gonzalez, S.; Duncan, S. E.; O'Keefe. S. F.; Sumner. S. S. \& Herbeln, J. H. (2003) : Oxddation and Textural CharacterIstics of Butter and Ice Cream whth Modlfled Fatty Acid Profles. J. Dalry Scl. 86:7077.

Harrigan, w. F. (1998) : Tcchniques for the microblological examination of foods. In Laboratory Methods in Food Microbiology. 3rd Ed.

Hettlnga, D. H. (1993) : Butter. In Y. H. Hul, ed., Encyclopedia of Food Technology. vol. 1. John Wilcy \& Sons. Inc., New York. pp. 231-237.
Hettinga, D. H. (2005) : Buller. In Bailey's Industrial O1l and Fat Products. Slxth Edition. Slx Volume SeL. Edited by Fereldoon Shahidı. Copyright John Wiley \& Sons. Inc).

Hitchins, A. D. (2001) : Listerla monocytogenes. US FDA/ CFSAN BAM.

Im. Jt-Soon, \& Marshall, R. (1998) : Effects of homogenization Pressure on the physleal. chemical and sensory properties of formulated frozen. Food Sel. Blothechnol. 7(2): 90-94.

Lawrence, R. C. (1976) : Microbial lipases and related esterases. Part 1 deteetion, distribution and production of mlerobial lipases. Dairy Sel Abst.. 29: 1-8.

Lewls, H. C.; Little, C. L.; Elson, R.; Greenwood, M.; Grant, K. A, \&, MelauchUn, J. (2006) : Prevalence of Listeria monocytogenes and other Listeria species In butter from United KJngdom produelion. retall, and catering premises. J Food Prot, 69(7): 1518. 26.

Luppi, A. \& Buccl, G. (1882) : Isolation of Yersinla enterocolitica from food in the provInce of Ferrara. Boll. 1st. Sleroter Milan. 61 (2): 158-160).

Iyaljala, R.; Lyytlkalnen, O.; Autlo, T.; Aaltto, T.; Hanviato, L. \& HonkanenBuzaloki, T. (2001) : Exposure of Listerta monocytogenes within an epidemic caused by butter in Finland. Int. J. Food microblal. 70 (1-2): 97-109.

Massa, S.: Gesaronl. D. \& \& TrovatelH, L. 
D. (1980) : The Incidence of Listerla species in soft cheese, butter and raw milk in the province of Bologna. J. Apll. Bacterlol., 68: 153-156.

Mohamed, S. M.; Ahdel-Rahman, H. A.: Morgan. S. D. \& Hafez, R. S. (1983) : Mycologlcal studies on Egyptian soft cheese and cooking butter. Assul Vet. Mcd. J., 11 (21): 151-155.

Murphy, M. F. (1890) : mlcroblology of buticr. In Dairy Microblology. Vol. II. 2nd Ed. (Robinson, R.K., ed.) Elsevier Applled Sclence. London and New York.

Nazem, A. M. (1991) : Assessment of the hyglenic quallty of some dalry products. Ph.D. 'Thesls. Fac. Vct. Med. Alex. Univ.

Nawar, Dalla, M. M. (2001) : Hyglerilc quality of some strcet-vended dalry products. M. V. Sc. Thesls Fac. Vet. Med. Alex. Unlv.

Patler, B.; Guven, A. \& Soltan, 6.(1985) : Studies on the quality of butter consumed in Elazlg (Turkey). Veteriner Blimerl Derglsl. 11 (1): 77-81. Dairy Scl. Abstracl., 58 (6): 458.

\section{US standards for grades of butter, 1992}

Rajarman, S.; Naraslmhan, R. E Khan, M. M. H. (1994) : Identiflation of yeasts and moulds in butter and lipolytic study of select. ed moulds. Indlan J. Dalry Scl., 47 (4): 341 . 345.

Sabreen, M. S. (1996) : Mlcroblological qually of imported and lucial processed (diceses and butter. 7 th Scl. cong. 17.19 November. Fac. Vet. Med. Assiut Univ.

Saleh, Omayma A A (1895) : Chenical and microblological paramclersaffecting on keeping qually of some dairy products. Ph. D. Thesis, Fac. Vet. Mcd, Alex. Univ.

Santos, E. G. Dos. C.; Ralmundo, S. M. \& Rohbs, P. G. (1995) : Microbiological evaluation of butter purchased from a market of Rlo de Janlero. I. Indicator and pathogenke microorganlsms. Revista de Microbiologla. 26 (3): 224-229.

Tasnlen, K.; Khalld, R. \& Chaudhry, M. Y. (1983) : Microblological status of different varteties of butter. Science International. 5 (1): $81-83$.

Tournas, V.; Stack, M. E.; Mislivek, P. B.: Kock. H. A. \& Bandler R. (2001) : Yeasls, Molds and mycoloxing. US FDA/ CFSAN BAM

Zhao, T.: Doyle, M. P. \& Berg. D. E. (2000) : Fate of Campylobacter Jejunl In butter. J. Food Prot. 63 (1): 120-122). (ISSN: 0362-028x). 
Sawsan, M. L. El-Sheshnagui; et al...

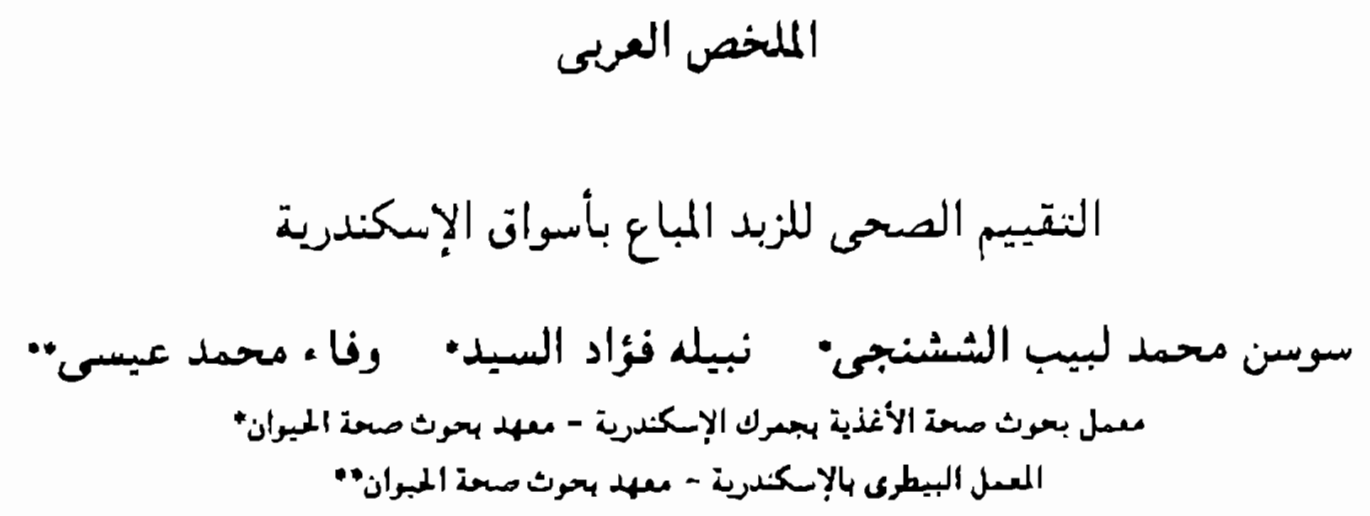

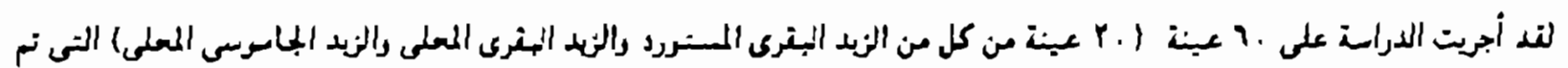

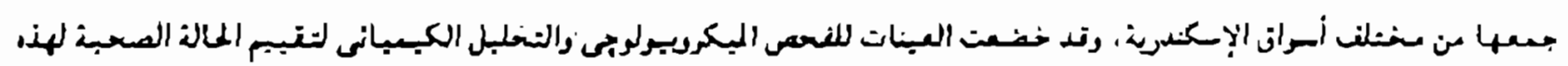

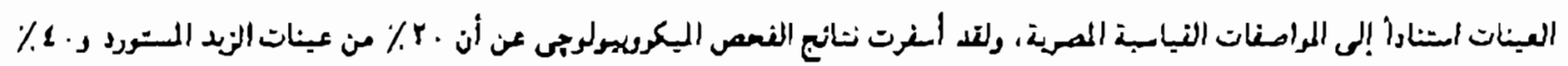

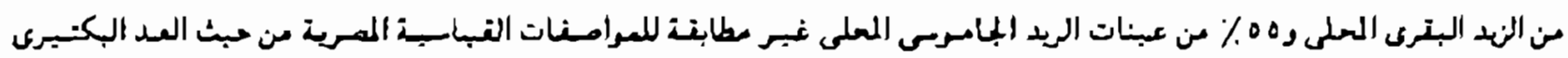

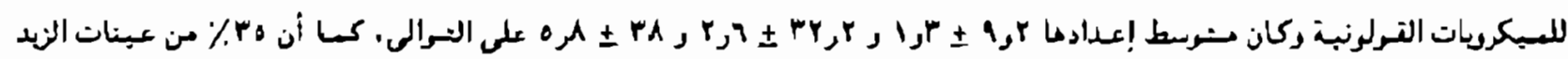

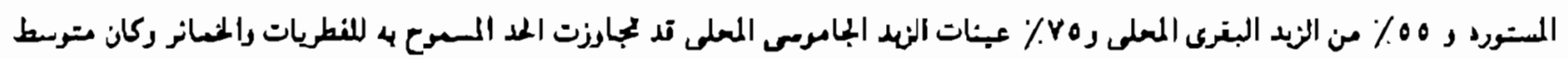

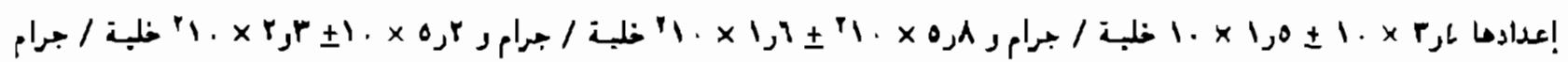

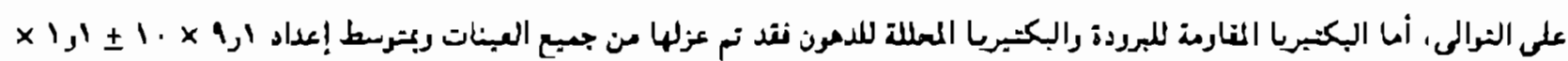

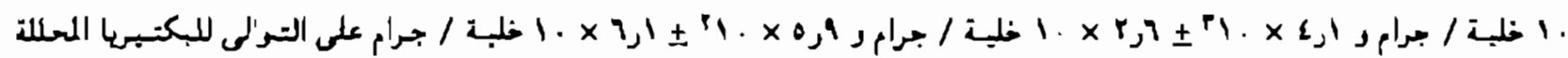
للدمون ر 0رو × .

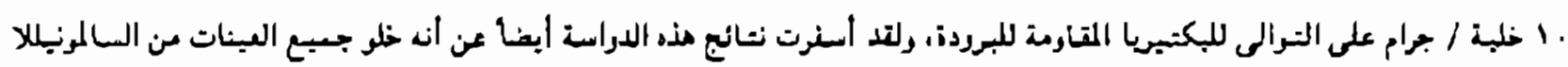

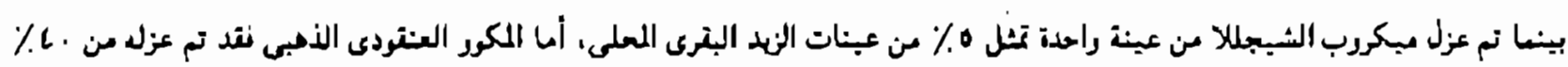

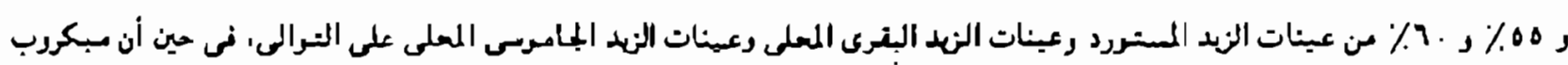

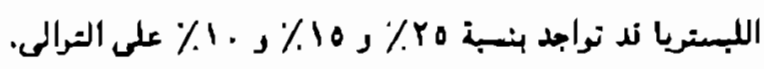

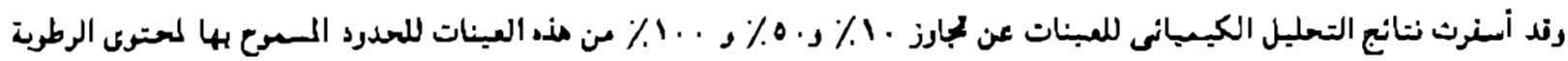

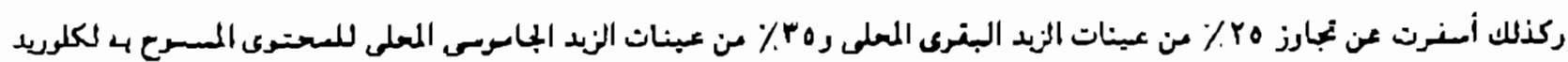
الصرديرم. 